\title{
Psychological Study on the Origin of Life, Death and Life after Death: Differences between Beliefs According to Age and Schooling
}

\author{
Jesús Silva Bautista, Venazir Herrera Escobar*, Rodolfo Corona Miranda \\ Faculty of Advanced Studies Zaragoza, the National Autonomous University of Mexico, México
}

Copyright $\mathrm{C} 2018$ by authors, all rights reserved. Authors agree that this article remains permanently open access under the terms of the Creative Commons Attribution License 4.0 International License

\begin{abstract}
The present work proposes a psychological study via beliefs, about the origin of life, death and life after death. Beliefs have played a decisive role in the development of humanity [1], from the primitive man who gave to the unknown divine forces, the judgments of the Holy Inquisition in the Medieval Age, the impact provoked by the conviction that the Earth was round on the belief of a flat Earth and many other beliefs that sustain the behavior of the human being. In this context, the need arose to investigate the beliefs held by inhabitants of the Metropolitan Area of Mexico City towards the origin of life, death and life after death and with it, to know if there are differences in function of age and schooling; for this, the scale of Silva, Herrera and Corona [2] was applied and with the purpose of obtaining the $t$ of Student and ANOVAS the statistical package SPSS version 21 was used. The results show statistically significant differences between beliefs and sociodemographic variables age and schooling. Schooling: The more educated the population in general, the less likely they are to have religious beliefs. Age: The group of people between 35 and 45 years old are the ones who show a tendency to believe in scientific postulates about death, unlike those who are 60 years old and older.
\end{abstract}

Keywords Beliefs, Lifetime, Death, Science, Religion

\section{Introduction}

When referring to the psychological thought of the human being, we immersed the conception about life and death because they represent their greatest enigmas. The human being has sought different ways of understanding these events, arising from explanations based on Biology, where all the organisms that are born have a development and die, placing death as a natural fact; to the search for spiritual events where physical death only occurs, because the conscience or the soul, as conceived does not die, hence the transit of souls, the transmutation to planes where redemption, reincarnation or resurrection can be achieved, depending on the religion or philosophical current that is professed [3]. Being for that reason, the foundation of the beliefs that the human being has had around its origin, death and subsequent lives throughout history.

Currently various disciplines such as Social Anthropology, Philosophy, Sociology, Psychology, Medicine or Neuroscience have ventured into the phenomenon of beliefs, as a basis to understand human behavior. Believing is a universal constant, belief was usually related to religion, however, belief is revealed as an ontological condition of the human being $[3,4]$.

In this contextual framework, denominating the intangible is something really complicated and subjective; therefore, sometimes the concept of belief is diffuse [4, 5], and in spite of the numerous investigations carried out controversial questions still exist around its definition [6]. However, there are different authors in the literature who have made an effort to define concretely what beliefs are. Pepitone [1] stated that "many beliefs refer to non-real entities in terms of a measurable material existence. Therefore, it is argued that beliefs are outside the limits of legitimate scientific research. The fundamental point that is lost sight of in this type of argument is simply that people maintain these types of beliefs. One could argue that whether or not there is a belief within a material objective order is of secondary importance compared to the reality with which people believe in its existence (p.62).

Beliefs according to authors such as Fishbein and Ajzen [7] refer to judgments of subjective probability of the relationship between the object of the belief and some other object, value, concept or attribute. This definition implies that the formation of belief involves the establishment of a link between any two aspects of the individual's world. 
The belief in addition to being a link between an object and an attribute with a certain level of probability can be conceived as a subjective initial condition that explains a set of apparently unconnected behaviors, and when understanding the cause as an initial condition, the belief is a cause of the behavior. Thus, to believe implies having a series of expectations formulated as hypotheses, which regulate the actions and relationships of the subject with the world around $[8,9]$.

On this line, Rokeach [5] states that beliefs are great presumptions about oneself and physical and social reality; "(...) simple conscious or unconscious propositions inferred from what people say or not, able to exist before said" (p.113). It also highlights three components of belief: a cognitive component, which represents knowledge; an affective component, capable of provoking emotion; and a behavioral component, activated when action requires it.

When taking into account the characteristics cited by this author, Pepitone [1] proposes four basic functions that encompass some of these elements. The first function refers to an emotional part, beliefs directly serve to manage emotions; the second function has a cognitive character, where they give cognitive structure, which provides a feeling of control over life; the third refers to a sense of morality, here beliefs work to regulate the distribution of moral responsibility between the person and the group; and finally, the group function, where beliefs promote group solidarity by giving people a common identity. On this last function, Pajares [5] adds that these provide elements of the structure of values, order, direction and shared values, which is why they acquire emotional dimensions and resist change.

For people to change their beliefs to accommodate new ones will require not only develop new behaviors, but also, abandon the well-established and apparently successful, which can lead to disorientation and frustration. Given this, Myers [10] argues that the human being constantly examines and justifies how the theories that guide his life could be true, thus closing the new information that challenges his beliefs. According to Fanon [11], sometimes the human being has a very strong fundamental belief. When evidence is presented that contradicts that belief, the new evidence cannot be accepted. This creates a deeply uncomfortable feeling called cognitive dissonance. And because it is so important to him, he will protect the fundamental belief, rationalize, ignore and even deny anything that does not conform to the fundamental belief. Therefore, the way of how certain beliefs are acquired is a vital process both to understand what man apprehends of the world, and to understand the beliefs that he considers true depending on the theory to which they belong [12]

A belief constantly inculcated in the first years of life, when the brain is more impressionable, seems to acquire almost the nature of an instinct; Most of the time they remain immutable in the face of contradictions caused by reason, time, teaching or experience; they are acquired through associative learning processes; but also, they have a cultural origin, insofar as they are built in formats of social interaction; they are a product of the construction of the world. They can be seen as incontrovertible personal truths that are idiosyncratic, with a lot of affective value and evaluative components that reside in episodic memory $[4,5,13,14,15]$. As a result, there is a wide variety of beliefs that give meaning to the action, they provide the elements of justification necessary to carry it out, maintain it, modify it, suspend it or end it [16].

Within the wide range of beliefs that make up thought and guide human behavior, according to Pepitone [1] can be recognized at least four major categories: natural-material, supernatural (religious and secular), psychological and moral. These beliefs are classified according to their conceptual properties, based on both common observation and intuition. However, sometimes "the classifications of beliefs are not always pure; Objective observers cannot always determine whether the referents of a particular belief are material or not. However, it is useful to differentiate between natural and supernatural categories "(p.64).

Within the classification that Pepitone [1] and De la Pienda [4] propose about beliefs, there are those of natural-material order, which "(...) refer to that which exists in the material world or that which can be defined as material at some level of analysis. The category includes scientific beliefs and beliefs about history and society" (p.64) [1].

Science is understood according to Gould $[17,18]$, as the objective search for truth; as one that "tries to document the objective nature of the natural world and develop theories that coordinate and explain such facts" (p.12). "The magisterium of science covers the empirical world: what the universe is made of (reality) and why it works the way it does (theory)" (p.14). It is an attempt to discover, through observation and reasoning based on observation, the particular facts about the world first, then the laws that connect the facts with each other, and that (in fortunate cases) make it possible to predict future events [19].

In this context, Estany [20] argues that science is the most important source of knowledge acquisition, a guarantee for the justification of the beliefs held by the human being, and expresses that "if justification is a fundamental epistemic notion and one from the requirements so that we can affirm that we have knowledge of something, science has to play an important role in supporting our beliefs. Science is considered as the cultural product that provides the most guarantees to justify our beliefs and the one that provides the most truths. This does not mean that it is the only one that provides knowledge, but there is no other cultural product whose intrinsic and primordial purpose is to provide knowledge about reality "(p.95).

If we accept that science has a specific range when it comes to the acquisition of knowledge, it is pertinent to 
analyze the rules of the game that are the principles, norms, and logical structure of science. These questions are the ones dealt by the philosophy of science, which thus becomes one of the pillars on which our beliefs are based (p.96) [20].

On the other hand, the human being lives different daily personal, environmental and socio-cultural events, processes that, most of the time involves existential reflections. Even when science and technology are one of the most accurate knowledge today, this often does not answer questions that are of a more spiritual nature, such as why and for what we live; therefore, within the belief system that the human being has to understand himself, the world and others, are those beliefs that are based on emotional experience and to which he adheres strongly, to the point of that it even maintains them against evidence against $[12,21]$; these beliefs are of a religious nature and are based on two important aspects.

The first refers to the function that religion fulfills in the search for eternal truth and absolutely certain in the explanation of the world as it is known, as well as in the sacred books or sacred writings where its main support is found, and which only they can remain intact if they are accepted as a whole [19]. The second is that religious beliefs are based on acts of faith; in sacred objects and places; in supernatural events such as immortality, resurrection, reincarnation and transcendence; as well as in a variety of gods, angels and other entities and spiritual powers that are located outside the field of the material; they deal with obedience in divine laws, miracles, the efficacy of prayer and the fate of the spirit in later lives [1, $16]$.

According to Darwin [13] (p.47) "the feeling of religious devotion is very complex: it is composed of love, of a complete submission to a mysterious and elevated superior, of a great feeling of dependence, of fear, of reverence, of gratitude, of hope for the future, and perhaps also of other feelings. Such a complex emotion cannot be felt by any being who has not reached some superiority of moral and intellectual faculties.

Religious beliefs are capable of giving true universality to the human spirit; whose functions are to provide the subject with an integral vision of reality as well as giving meaning and meaning to the world. A religious life that implies beliefs in certain dogmas and a certain way of feeling the ends of human life helps man to diminish the sufferings of humanity, the problems of human destiny and to have greater hope that in the future he will have the best possibilities of its kind [19, 22, 23].

In general terms, human beings live according to their beliefs [4]. These allow you to operate in the world; they form the basis of life, the terrain on which it takes place; in them you live, you move and you are. There is no behavior that is not constituted by them $[1,24]$.

Indistinctly of the culture, age, race, sex, profession or educational level, every human being always sees himself in the need to confront certain universal conditions of existence, and from there to create his own and particular project of life. At the same time that it is part of the world, it is also a being capable of constituting said world, because it is who interprets and gives meaning to it $[25,26,27]$. Consequently, this need to give meaning to everything that is and happens has led to the need for some values to govern, values that must offer an answer to the supreme questions about life and death.

\section{The Origin of Life}

The more you learn about the Earth, the clearer it is that the surface of our planet has been greatly altered by the origin, evolution and growth of life in it. As life develops, the composition, temperature, and chemical nature of Earth's atmosphere, texture, and diversity are altered. The environment on the surface and the organisms have been evolving together in it for billions of years [28, 29].

The scientific study of the beginnings of the world has posed, in historically recent times, the biological questions of the origin of life and the evolution of species [30]. Scientists have used gene sequences and morphological data to build tens of thousands of evolutionary trees that describe the evolutionary history of animals, plants and microbes. The understanding that all organisms on Earth are related by common descent was one of the deepest ideas in scientific history [31].

Under this contextual framework, the scientific beliefs that deal with the origin of life are based on the principles of Charles Darwin's Theory of Evolution [13, 32]; this theory is one of the works that has had more importance in the consolidation of scientific thought [33]. This theory affirms that all beings are the product of the process of natural selection initiated not by a Universal Mind or by a Divine Intelligence but by the random and arbitrary accumulation of environmental modifications indicated by algorithms that allowed the configuration of a certain type of order, capable of to create, develop and evolve certain types of organisms that managed to rise to the possibility of controlling their own development. This process of evolution, in principle arbitrary, ended up forming organisms with a certain phenotypic distribution capable of harboring primitive minds, mechanisms capable of taking charge of their own modifications [34]. Under these terms, evolution occurs through the transmission from one generation to the next of what the individual biological entities learn or acquire in their confrontations with the environment; consequently, the variations that are observed in the species in nature can be inherited; some of these variations grant adaptive advantage and their carriers will survive; thus, a natural selection, a material law that eliminates the need for an invisible hand of the Universe, is produced and therefore "the theory of evolution is complete in itself and does not require the intervention of mysterious forces alien to the scientific understanding" [35, 36]. In Darwin's directed words [37] 
(p.52) to Desmond and Moore: "It is very hard to believe that the tail of a peacock was formed in this way, but, once I believed this, I believe on the same principle, something modified, applied to man".

This introduces not only the existence of scientific beliefs about the origin of life, but also a series of beliefs that are forged from the divine intervention or a higher entity, giving rise to religious beliefs. According to Barahona [33] discussions between the Church and science, on this subject, have a long history. The position that religion has maintained, especially the Catholic Church, has polemicized with the theory of evolution, in particular on whether the human being has evolved or not, and whether or not he shares traits with primates. But this is a purely scientific issue and there are evidences from many disciplines, such as Paleontology, Anthropology, Molecular Biology or Genomics that currently offer good reasons to believe that what the theory of evolution as natural selection holds has happened, that is, allows to believe that evolution is a fact. While the Church is based on principles that are not verifiable (acts of faith); science when confronting religions does so with arguments that are incompatible with faith. Scientific knowledge is proven, there are different methodologies to be able to explain phenomena and be able to infer laws, which are the explanatory frameworks of these natural phenomena, and religion does not work that way.

However, for centuries the main positions on the origin of life have emerged from religion, an example of this is the Judeo-Christian tradition. Judeo-Christianity holds that human beings are made in the image and likeness of God and bear no relation to animals. The mind is an immaterial substance that has powers that are not based purely on the physical structure and can continue to exist when the body dies. Man is conceived as the creation of a transcendent God who has a determined purpose for life, therefore, the destiny of man depends on his relationship with God [38].

Another position of a religious type is Creationism [17, 18]. It supports the a priori acceptance of the existence of a supernatural structure that puts order in things. As a consequence of this divine order, the place that corresponds to each species is predetermined and immutable. Therefore, it rejects any idea of evolution and admits only what is established in the Bible [39].

Linked with the two previous positions, the Intelligent Design Theory holds that certain finite material objects exhibit patterns that convincingly point to an intelligent cause. Accepts scientific explanations about the origin of life, but with certain limitations, that is, considers the evolutionary process as a basically divine work subject to laws given by an intelligent agent (God / Higher Self / Breath or Divine Force) [40, 41].

Therefore, religious beliefs about the origin of life respond to the need of the human being to understand its origin and nature based on the existence of an omnipotent and benevolent Creator, who reveals to his creatures the knowledge of his decrees, reveals to each human heart what is right and what is bad, through it miracles can be explained and allows to confer to every event in the world a sense of transcendence. He is perfection itself $[1,19,22$, $42,43]$.

In general terms, Ruiz-Mirazo and Moreno [44] express that there is no magic in the origin of life, but we are facing an extraordinarily intricate phenomenon with profound implications, both scientific and religious, without neglecting the philosophical ones.

\section{Death and Life after Death}

"From the vast world of enigmas that disturb men, there is an ineffable subject for human understanding, apart from that of life. Subject that worries and reveals the man, and that he has not been able to decipher, no matter how much he wants to do it. It is about the phenomenon of death". (p.60) [45].

Death, as the final and inevitable destiny of man, transcends beyond a mere biological fact, because it brings with it important repercussions from the anthropological, psychological, moral, social, philosophical, religious, etc. points of view. The mysterious character of death and the sufferings that normally precede it, have impressed strongly the man of all times.

From the scientific conception, Montiel (p.60) [45] points out that death is defined as follows: "Death occurs when the fundamental functions cease: cardiac activity and respiratory activity, these bring about the cessation of functions cerebral and with this the whole existence ends ". However, for this author it should be taken into account that research has shown that this cessation of the activity of the organism is not very reliable, as there have been cases that this clinical death has been diagnosed but in which reanimation has been possible. This must occur before a certain time, before there is irreparable damage to the brain due to lack of oxygen. Such patients were clinically dead, but only clinically; this means that these patients had not died biologically. Biologically dead means that at least the brain has completely and irrevocably ceased to function. The biological death is brain death (the central death) and finally the death of the whole organism (total death)". [46]

In Mexico according to The General Health Law [47] Title XIV: Donation, transplants and loss of life, Chapter IV: Loss of life, Article 343, loss of life occurs when brain death or death occurs irreversible cardiac arrest. Brain death is determined when the following signs are verified (p.104):

1. Complete and permanent absence of conscience;

2. Permanent absence of spontaneous breathing, and

3. Absence of brainstem reflexes, manifested by pupilar areflexia, absence of ocular movements in vestibular tests and absence of response to nocioceptive stimuli.

For its part, the World Medical Association [48] 
through the Declaration of Sydney on the certification of death and recovery of organs states that death is a gradual process at the cellular level, in which the capacity of tissues to counteracting the lack of oxygen varies, but from a clinical and philosophical point of view, death has nothing to do with the preservation or not of isolated cells, but with the disappearance of the inherent characteristics of the human being.

The main point of the above is not in the simple declaration of death, but in the determination of the so-called point of no return that marks the moment when irreversibly ceases any possibility of recovery, the limit beyond which all hope of return to life is discarded.

As a negation of life, death is something that directly impacts, is what each human being takes into consideration for the simple reason that represents the end of their existence. Unlike other living beings, the human being is provided with the knowledge of its irremediable end and, at the same time, resists this event. Consequently, it revolts against death and tries to affirm its existence beyond real life, because the acceptance or rejection of death is directly influenced both by its representation and by the belief in a life after it. . From this fact springs the dualism inherent in any believer in the existence of the soul in the hereafter $[49,50]$.

From the Christian standpoint, the understanding of death is centered on the expectation that an encounter with God is made, who judges the facts of life and whose destiny is eternity [51, 52]; in this way, God rewards men after death. According to Von Wobeser [53] Christ promises his followers eternal life, in his company and God the Father, while threatening those who turn away from him with eternal punishment. In this sense, earthly life is only transient, for full existence begins after death; with this, the idea of immortality becomes one of the cornerstones of Christianity.

In this regard, Díez [54] (p.143) alludes to immortality "(...) as what makes one suspect a lack of knowledge, that is, a concealment of the fact of having to die and a blindness that is based on the belief where it seems to be reflected a puerile disbelief in one's death". In other words, that is absolute impossibility of dying, or else, the passage from a mortal to an immortal life. These beliefs can be explained by referring to the resurrection of Jesus Christ: the victory of Christ over death.

The belief in immortality is reinforced in the Catholic tradition with the idea that man is made up of body and soul, two distinct entities that coexist in the life of a person and separate at the time of death. While the soul is conceived as a spiritual entity, the body is considered impure, corruptible and perishable. At the moment of death, the soul travels to the beyond, to one of the places assigned by God, while the body stays on the earth, subject to a process of decomposition [53].

Under these terms, people seek ways to make it possible to live with the inexorability of death, as well as cultural inventions, the most prominent being the idea that death is not the end of the world, but a transition from a world to another, where those who die do not leave the only world that exists and dissolve and disappear into the beyond of non-being, but simply move to another world, where they continue to exist in a different way [55]. The present corporeal existence can be no more than a recurrent episode of an interminable but constantly changing existence as regards form or an opening towards an eternal life of the soul that begins with death. In this way, the certainty of the existence of a subsequent life and a chain of successive lives is maintained [56,57].

In summary, two main positions are presented: on the one hand, scientific reflection that poses a hidden function or function of death, often expressed in terms of selective advantage based on mechanisms of evolution; and on the other hand, the religious position where death is assumed as an arbitrary fatality, imposed against our will. Death is perceived not as the conclusion of a cycle, but as a possibility always present in human existence. The human being is the only species that is accompanied throughout his life by the idea of death [50].

As mentioned before, the human being always sees himself in the need to confront certain universal conditions of existence, and from there to create his own and particular life project [25]. Project in which, the beliefs that have towards the origin of the life, the death and the life after the death play a fundamental paper; however, there are other variables that together with beliefs have also been associated with the way we explain and understand our world, such as age, schooling or intelligence.

As an example, we can find the investigations carried out by Leuba [58], Larson and Witham [59] and Pérez-Agote and Santiago [60] who were interested in knowing the postures of scientists face issues such as the origin of life, the existence of God and life after death.

The research conducted by the psychologist Leuba [58] The belief in God and immortality. A Psychological, Anthropological and Statistical Study represent a study on the religious beliefs present in American scientists. The hypothesis put to the test was that the more educated people are, the less likely they are to believe in God. The author attributed this to the better education of scientists, and predicted that with the passage of time and the increase in education of the general public, religious beliefs will become increasingly rare. Conkin [58] reports that today, the higher the educational level of individuals, or better their results in intelligence or performance tests, the less likely they are to be Christians.

The study of Larson and Witham [59] Leading scientists still reject God revolves around the existence of a God and the belief in immortality that scientists have, specifically biologists, physicists and mathematicians. The authors conducted a survey of selected scientists from the American Men and Women of Science, which lists a 
general list of American scientists. The instrument used represents a replica of the surveys used by Leuba in 1921. The results obtained coincided with those of Leuba [58], which revealed that most scientists openly proclaim themselves atheists and deny the fundamental truths of the faith.

On the other hand, the data available for the survey on religious attitudes and beliefs prepared by the Center for Sociological Research (CIS) in Spain and published by $\mathrm{ABC}$ News [60] point in the same direction, as the level of education increases, the belief in God decreases.

The study performs a descriptive analysis of different indicators that may affect the process of secularization. We study aspects related to some sociodemographic variables, such as age, socioeconomic level and level of studies. The authors of this important study conclude that "Spanish society tends to grow at its average level of studies and, with it, to decrease in its level of religiosity" (p. 313) [60].

Continuing with this line of research, the article published in Personality and Social Psychology Review entitled The Relation Between Intelligence and Religiosity: A Meta-Analysis and Some Proposed Explanations by Zuckerman, Silberman and Hall [61], shows a meta-analysis of 63 studies that show a significant negative association between intelligence and religiosity. Of the total number of studies analyzed, 53 of them showed a negative correlation between intelligence and religiosity; while the other 10 studies showed a positive correlation; that is, from a statistical point of view, high values in intelligence correspond to low values in religiosity. According to Zuckerman, et al. [61], correlation does not mean causality; however, it is not known if there is a causal relationship and do not rule out other possible factors that may influence the correlation; for example, other variables such as age, sex, race or education were analyzed. The first three did not affect the correlation, in the case of education, only one study established that it did, but the correlation between education and religiosity was also negative. In general terms, the authors state that, according to the results found in the meta-analysis of the 63 studies, intelligent people or with certain studies have less need for religious beliefs and practices.

As it is observed, theoretically the main element of analysis in these investigations are the beliefs, religious beliefs specifically on the origin of the life, the existence of God and the life after the death. For this reason, from the Social Psychology, the need arose to investigate the beliefs held by the inhabitants of the Metropolitan Area of Mexico City towards these phenomena of reality and with it, to know if there are differences according to age and schooling. According to Angarita and De Castro [25] and Craig [62] the beliefs towards these phenomena are different according to the psychological maturity of the individual and the influence of the frames of reference as varied as culture, personality, philosophy of life, religious orientation, age, sex, socioeconomic level, IQ, schooling, among others.

\section{Materials and Methods}

\section{Participants}

An intentional non-probabilistic type sample was chosen, composed of 913 inhabitants of the Metropolitan Area of Mexico City, of which $49.8 \%$ are men and $50.2 \%$ are women; $46.4 \%$ are single while $53.6 \%$ are married. In terms of age, $22.7 \%$ are between 18 and 30 years old, $26 \%$ between 31 to 45 years old, $28.9 \%$ are between 46 and 60 years old, and $22.5 \%$ are 61 years of age and older. Of the selected sample, $57.3 \%$ have only basic education, while the remaining $42.7 \%$ have a doctoral degree. Finally, $71.3 \%$ of the total sample is a believer in God, in a Higher Being or in some other divinity, while $28.7 \%$ is not.

\section{Instrument}

The instrument that was used to measure beliefs about the origin of life, death and life after death was the scale of Silva, Herrera and Corona [2]. The scale is made up of four study factors:

FACTOR 1. Religion: Origin and Life after death. Factor that represents religious beliefs towards God or a divine agent as creator of life in the Universe, of what transcends the material world and that puts man and the Universe in contact with what is beyond matter, leaving side the evolutionary theory. In this sense, God is the one who will resurrect men at the end of time; the being who created the world as it is known, man in his image and likeness; the one who gives the virtue of immortality to the human being. Likewise, an eternal life is recognized, a soul and a body that will be reunited again in their perfect form at the end of time. Death is conceived as the beginning of a life in heaven, the passage to another life where the full existence of the human being begins after his death. The positions that support this factor are Creationism [17, 18], Judeo-Christianity [38] and Theory of Intelligent Design $[40,41]$.

FACTOR 2. Darwinism. The basis of this factor is supported by the Theory of the Evolution of Species [32], where it is assumed that this theory is the most rational explanation about the origin of man and scientific evidence is essential to explain the origin of living beings.

FACTOR 3. Death: Scientific advances. The content of this factor alludes to the fact that death is a phenomenon of inescapable reality, where advances in science such as genetic modification, studies on aging or cloning can become a tool to postpone death indefinitely.

FACTOR 4. Science: Conceptualization of Death. Dying is the end of the existence of the human being, of the existence of every living being on Earth [45].

As can be seen, factors 2, 3 and 4 are based on scientific 
principles in the explanation of the origin of life and the phenomenon of death.

The instrument has 48 items distributed equally between the two study categories, with a Likert-type response scale of five intervals $(1=$ Strongly disagree, 2 = Disagree, $3=$ Neither agree, nor disagree, $4=$ Agreement, $5=$ Strongly agree). Reliability is given by a value of Cronbach's alpha coefficient of .874 and a total explained variance of $56.953 \%$.

\section{Procedure}

The scale was applied in universities, parks, shops and crowded places in the Metropolitan Area of Mexico City. In the first instance, the possible participants were contacted mentioning the objectives, characteristics, conditions of the study and the confidentiality of the information provided in case of acceptance. Once accepting to be a participant, each of the applicators proceeded to read the instructions for filling the instrument, ensuring that the participants fully understood the request. The participants answered the scale in an approximate time of 10 to 15 minutes and the total application of the scale was carried out in a period of approximately five weeks. Once the information was collected, we proceeded to the statistical analysis of the data obtained.

\section{Results}

With the purpose of knowing the beliefs that inhabitants of the Metropolitan Zone of Mexico City have towards the origin of life, death and life after death according to their age and schooling, the analysis of the Student's $t$ for independent samples and analysis of variance (ANOVA).

\section{Student's t for Independent Samples}

\section{Schooling}

The results show that there is a statistically significant difference between the averages of the four study factors in relation to the sociodemographic variable of schooling (See Chart 1).

Chart 1. Student's t for schooling variable

\begin{tabular}{|c|c|c|c|c|c|}
\hline Factor & VS & Avg. & $\mathbf{t}$ & gl & Sig. \\
\hline \multirow{2}{*}{$\begin{array}{c}\text { FACTOR 1. Religion: } \\
\text { Origin and Life after } \\
\text { death. }\end{array}$} & Basic & 3.48 & \multirow[b]{2}{*}{18.090} & \multirow[b]{2}{*}{911} & \multirow[b]{2}{*}{.000} \\
\hline & $\mathrm{PhD}$ & 2.20 & & & \\
\hline \multirow{2}{*}{ FACTOR 2. Darwinism } & Basic & 2.75 & \multirow{2}{*}{-2.205} & \multirow{2}{*}{911} & \multirow{2}{*}{.028} \\
\hline & $\mathrm{PhD}$ & 2.89 & & & \\
\hline \multirow{2}{*}{$\begin{array}{l}\text { FACTOR 3. Death: } \\
\text { Scientific Advances. }\end{array}$} & Basic & 3.63 & \multirow{2}{*}{-1.976} & \multirow{2}{*}{911} & \multirow{2}{*}{.049} \\
\hline & $\mathrm{PhD}$ & 3.75 & & & \\
\hline \multirow{2}{*}{$\begin{array}{l}\text { FACTOR 4. Science: } \\
\text { Conceptualization of } \\
\text { Death. }\end{array}$} & Basic & 3.22 & \multirow[b]{2}{*}{-12.898} & \multirow[b]{2}{*}{911} & \multirow[b]{2}{*}{.000} \\
\hline & $\mathrm{PhD}$ & 3.96 & & & \\
\hline
\end{tabular}

In Factor 1 Religion: Origin and Life after death people with basic education $(\mathrm{M}=3.48)$ tend to be in agreement with beliefs towards supernatural events such as immortality, resurrection and transcendence; to believe that death is the passage to another life, or, that it means the beginning of life in heaven, hence at the moment when the human being recognizes the greatness of God, he obtains eternal life. They assume that from the supreme sky of the Universe, God created the world as it is known. These beliefs mark a significant difference of 1.28 units over the average of people who have an academic degree of doctoral studies $(\mathrm{M}=2.20)$ who disagree with these beliefs.

The results of Factor 2, Darwinism indicate that it is the people with a doctoral degree $(M=2.89)$ who agree with the position that the genetic constitution of living beings is the result of natural selection; in addition, the complexity of the biological structure of organisms on Earth is the result only of the process of evolution and with it, that scientific evidence is the only way to know the origin of the Universe. Unlike people with basic education $(\mathrm{M}=2.75)$ who with a difference of .14 units between their respective averages are in disagreement with Darwinian scientific beliefs.

On the other hand, to believe that advances in science will be a solution to save humanity from the phenomenon of death is the essence of Factor 3 Death: Scientific advances. In this factor people with basic education $(\mathrm{M}=3.63)$ tend to disagree, unlike people with a doctoral degree $(\mathrm{M}=3.75)$ who are in favor of this belief; the difference between their respective averages is .12 units.

Finally, in Factor 4 Science: Conceptualization of Death, as a scientific vision where death is believed to be the end of the existence of the human being, of every living being on Earth, once again it is the people with the academic degree of $\mathrm{PhD}$ students $(\mathrm{M}=3.96)$ who agree with this belief, unlike people with basic education $(\mathrm{M}=3.22)$ who do not agree with it, marking a statistically significant difference of .74 units between their averages.

In summary, the Student $t$ results indicate that in the four factors the tendency of people with basic schooling is to believe in religious principles, unlike the people with the doctoral degree, who base their beliefs on a series of rational ideas that allow them to generate objective knowledge based on science.

\section{Analysis of Variance (ANOVA)}

Age

According to the results of the simple variance analysis there are statistically significant differences between the averages obtained in the variable age with respect to three of the four study factors. Factor 1. Religion: Origin and Life after death $(\mathrm{F}=9.615, \mathrm{gl}=3, \mathrm{p}<.000)$; Factor 3. Death: Scientific advances $(\mathrm{F}=6.193, \mathrm{gl}=3, \mathrm{p}<.000)$ and Factor 4. Science: Conceptualization of Death $(F=3.169, g l=3, p$ $<.024)$ are significant, not so, Factor 2. Darwinism (F $=.512, \mathrm{gl}=3, \mathrm{p}<.674)($ See Chart 2). 
Chart 2. Analysis of variance (ANOVA) for the Age variable

\begin{tabular}{|c|c|c|c|c|c|}
\hline Factor & VS & Avg. & gl & $\mathbf{F}$ & Sig. \\
\hline \multirow{4}{*}{$\begin{array}{l}\text { FACTOR 1. } \\
\text { Religion: Origin } \\
\text { and Life after } \\
\text { death. }\end{array}$} & 18 a 30 years & 2.94 & \multirow{4}{*}{3} & \multirow{4}{*}{9.615} & \multirow{4}{*}{.000} \\
\hline & 31 a 45 years & 2.70 & & & \\
\hline & 46 a 60 years & 2.84 & & & \\
\hline & 61 and older & 3.30 & & & \\
\hline \multirow{4}{*}{$\begin{array}{c}\text { FACTOR } 2 . \\
\text { Darwinism }\end{array}$} & 18 a 30 years & 2.85 & \multirow{4}{*}{3} & \multirow{4}{*}{.512} & \multirow{4}{*}{.674} \\
\hline & 31 a 45 years & 2.85 & & & \\
\hline & 46 a 60 years & 2.79 & & & \\
\hline & 61 and older & 2.75 & & & \\
\hline \multirow{4}{*}{$\begin{array}{l}\text { FACTOR 3. } \\
\text { Death: Scientific } \\
\text { Advances. }\end{array}$} & 18 a 30 years & 3.46 & \multirow{4}{*}{3} & \multirow{4}{*}{6.193} & \multirow{4}{*}{.000} \\
\hline & 31 a 45 years & 3.75 & & & \\
\hline & 46 a 60 years & 3.70 & & & \\
\hline & 61 and older & 3.79 & & & \\
\hline \multirow{4}{*}{$\begin{array}{c}\text { FACTOR } 4 . \\
\text { Science: } \\
\text { Conceptualization } \\
\text { of Death }\end{array}$} & 18 a 30 years & 3.47 & \multirow{4}{*}{3} & \multirow{4}{*}{3.169} & \multirow{4}{*}{.024} \\
\hline & 31 a 45 years & 3.62 & & & \\
\hline & 46 a 60 years & 3.62 & & & \\
\hline & 61 and older & 3.40 & & & \\
\hline
\end{tabular}

In Factor 1. Religion: Origin and Life after death $(\mathrm{F}=9.615, \mathrm{gl}=3, \mathrm{p}<.000)$ people who are in an age range between 31 to 45 years $(\mathrm{M}=2.70)$ they believe in divine laws or the fate of the soul in later lives, either, in a personal God who is omnipotent, omniscient and perfectly good, who created and controls everything that exists in the Universe, unlike people who are 61 years old and older $(M=3.30)$ who believe in a divine order, where the place that corresponds to each species is predetermined and immutable. For this reason, most of the time they reject any idea of evolution and admit only what is established in the Bible. The difference between the averages of each group is of .6 units

Regarding Factor 3. Death: Scientific advances $(\mathrm{F}=6.193, \mathrm{gl}=3, \mathrm{p}<.000)$ are people who are in the range of 61 years and older $(M=3.79)$ who believe that scientific studies on the Aging, the technology of cloning and genetic modification are resources that will help to save the human being from death; unlike people who are between 18 and 30 years $(\mathrm{M}=3.46)$ who do not believe in it, marking a statistically significant difference of .33 units between their respective averages.

Finally, with a difference of 22 units between the means of the people who are in the range of 31 to 45 years $(\mathrm{M}=3.62)$ and of 46 to 60 years $(\mathrm{M}=3.62)$ on people of 60 years and older $(\mathrm{M}=3.40)$ in Factor 4. Science: Conceptualization of Death $(\mathrm{F}=3.169, \mathrm{gl}=3, \mathrm{p}<.024)$ are the first who believe in the end that death is nothing more than the total cessation of function cerebral, of cardiac and respiratory activity, bringing with it the end of the existence of the human being and with it, the total rejection of a life after death.

In short, as mentioned by Angarita and De Castro [25] and Craig [62], the beliefs held about these phenomena of reality are different depending on the individual's psychological maturity and the influence of frames of reference such as culture, religious orientation, age, sex, socioeconomic level, schooling, or, of the needs that are specific to each subject and that help him to confront certain universal conditions of existence.

\section{Discussion}

The scientific study of the beginnings of the world has raised, in historically recent times, the biological questions or not of the origin of life; the existence or not of life after death; as well as, the conflicts that arise between scientific and academic communities, the diverse explanations provided by science and religion to these phenomena of reality. The various conflicts, disputes and controversies revolve around questions about the "compatibility or incompatibility" of these two forms of knowledge, therefore, in these situations, in order to want to know and explain the way in which the human being shapes the relationships that keep it in contact with everything that exists, studies conducted specifically from social psychology have focused their interest in wanting to know the differences between beliefs towards these phenomena according to variables such as schooling (formal education), age, sex, the IQ or the socioeconomic level.

In the case of the differences found between the groups of people with basic education and the people with doctorate academic degree according to the four factors that represent the religious and scientific beliefs about the origin of life, death and life after death, show that it is the people with doctorate degrees who show a clear tendency to believe in postulates whose foundation is a scientific explanation. They are based on a series of rational ideas that allow them to generate objective knowledge and work with certain methodological processes that are ascribed to empirical models oriented to the verification of hypotheses by methods and theories. In this sense, rational (scientific) knowledge comes from formal education, which constitutes a theoretical-practical educational process of an integral nature, oriented to the development of knowledge, skills, attitudes and values, which allow it to act and understand dynamically, critically, analytical and reflectively the events of his world around $[12,20,33$, 61].

On the other hand, the religious beliefs present in people with basic education have as a principle the value of a diversity of religious elements; elements that represent symbols of society, whose sacred character derives from its function to maintain and promote obligations, norms and social values; likewise, they act as a strong emotional component that allows man to both relate through a complete submission to a mysterious and elevated superior being, and to feel and act with a great 
feeling of dependence, fear, reverence and gratitude towards him $[1,5,14,51,52,53,63,65]$.

The differences found in the beliefs towards the origin of life, death and life after death in relation to schooling showed that by increasing the level of education, belief and religious practices decrease $[58,59,60,61,66]$.

According to Gervais and Norenzayan [66] and Zuckerman et al. [61], given that formal education and analytical thinking influence people's religious disbelief, these processes can undermine the intuitive support of religious belief, since it emerges thanks to the convergence of a series of intuitive processes and common sense. That is, people with high academic studies are able to stop the magical and supernatural thinking and tend to face the uncertainties of life on a rational-critical-empirical basis.

Formal education and analytical thinking have transformed the concept of the Universe in which the human being lives, continuously modifying their daily life, in such a way that their understanding of the structure of the Universe and the mechanisms of life are essential contributions of the science. The importance of science reaches such extremes that within a few years the most important trade on Earth will not be that of products, but that of scientific knowledge $[1,12,20]$. However, scientific ideas with their concepts and methods have not penetrated popular culture; for that reason, the general public knows little of scientific advances and even less understands them; consequently, non-scientific (religious) beliefs abound in people who lack a high level of education, making them the only way to explain and interact with their surrounding world.

On the other hand, the differences found between the beliefs towards the origin of life, death and life after death according to the age of the persons, indicates that those who are between the ages of 31 and 60 do not believe in immortality, in which at the moment of death, the soul travels to the beyond, to one of the places assigned by God, while the body stays on the earth, subject to a process of decomposition [53]. They do not have the certainty of the existence of a later life and a chain of successive lives $[56,57]$. They consider that the biological death is the cerebral death (the central death) and finally the death of the whole organism (the total death) [46]; unlike people who are 61 or older who believe in a divine order, where the place that corresponds to each species is predetermined and immutable; or, they focus on the expectation that when they die, they come to an encounter with God who judges the facts of life and whose destiny is eternity $[51,52]$. For this group, earthly life is only transient, for full existence begins after death; with this, the idea of eternity becomes a central axis in their lives.

One of the most interesting results that emerged in the study was the fact that people who are in an age range from 61 years onwards fully believe that scientific studies on aging, the technology of cloning and genetic modification are resources that will help save the human being from death; unlike people who are between 18 to 30 years who do not believe in it. If we bear in mind that the first group, in turn, believes in questions of a religious nature about the origin and life after death, we are faced with the uncertainty that these phenomena cause in the human being. As pointed out by Montiel (p.60) [45] "From the vast world of enigmas that disturb men, there is an ineffable subject for human understanding, apart from that of life. Subject that worries and reveals the man, and that he has not been able to decipher, no matter how much he wants to do it. It's about the phenomenon of death".

According to the World Medical Association [48] death is significant for the human being because it has to do with the total disappearance of the characteristics that are his own. The main point of the above is in the determination of the so-called point of no return that marks the moment in which irreversibly ceases any possibility of recovery, the limit beyond which all hope of return to life is discarded.

As a negation of life, death is something that directly impacts, is what each human being takes into consideration for the simple reason that represents the end of their existence. Unlike other living beings, the human being is provided with the knowledge of its irremediable end and, at the same time, resists this event. Consequently, it revolts against death and tries to affirm its existence beyond real life, because the acceptance or rejection of death is directly influenced both by its representation and by the belief in a life after it $[49,50]$.

Therefore, the results found may seem contradictory in people who believe in a life after death or in eternity, also believe that scientific advances can prolong their lives, and even save them from total death. According to Ornelas [22], Russell [19] and Schleiermacher [23] religious beliefs are capable of giving true universality to the human spirit; whose functions are to provide the subject with an integral vision of reality as well as giving meaning and meaning to the world. A religious life implies that beliefs in certain dogmas and a certain way of feeling the ends of human life, help man to diminish the sufferings of humanity, the problems of his destiny when death approaches and to have greater hope in a life beyond; Despite this, if these feelings of separation could be avoided for a certain period, for which it is known as "irretrievable", with the hope of lasting more, it is undoubted that the human being will seek to do so. Usually, this is where, most of the time, a deeply uncomfortable feeling called cognitive dissonance [11] is generated between the religious belief of eternal life and the scientific belief that can lengthen life in this world.

When the human being enters the compression of death as a process of human nature, a revolution of uncertainties that seem terrifying, insecure and threatening can be generated in him; then, when it reaches a certain age, this may seem more distressing, since it means the total end of 
its existence.

The relationships observed between age and religious beliefs, are explained according to Argue, Johnson and White [67] generally by three theoretical processes: the first is the traditional model that focuses on development processes related to age itself; the second is the life model that attributes change not to development processes but to correlated changes in social roles, particularly in the family; and finally, through an interpretation that characterizes the variations in religiosity by age as an associated statistical artifact with either the cohort replacement or epoch effects. These authors suggest that aging itself is associated with an increase in religiosity independent of the events of the course of family life. In general terms, the relationship between age and religious beliefs in daily life seems to be a smooth curvilinear function with the greatest change in the first years of adults. Whatever the case, beliefs toward death or life after it, frighten by the idea of possible suffering in the process of dying, or, by thinking if there really is an after death.

In general terms, the negative relationship between scientific and religious beliefs has a nuance, while religion and science make claims about reality and, due to their respective claims, often differ. This difference has brought consequences in the decisions and actions of the human being, where many times this has been forced to choose a version of reality $[19,23,68]$.

It should be remembered that the human being assumes in his daily life a version of that reality, for that reason, his beliefs can be seen as a conceptual substrate that plays an important role in his thought and action. These allow you to operate in the world; they form the basis of life, the terrain on which it takes place; in them you live, you move and you are. There is no behavior that is not constituted by them $[1,5,24]$. Therefore, it is very important that within the objectives of education, discussion and verification be encouraged as much as possible $[4,69]$.

\section{Gratitude}

This research was carried out thanks to the Support Program for Research Projects and Technological Innovation (PAPIIT) of the DGAPA-UNAM with password $<<$ IN $303316>>$

\section{REFERENCES}

[1] Pepitone A. El mundo de las creencias: un análisis psicosocial. Revista de Psicología Social y Personalidad. 1991; 7 (1), 61-79.

[2] Silva J; Herrera V. y Corona R. Scientific and Religious Beliefs about the Origin of Life and Life after Death:
Validation of a Scale. Universal Journal of Educational Research. 2017; 5 (6): 995-1007. DOI: 10.13189/ujer.2017.050612

[3] Torres C. Estudio sobre las creencias en torno a la vida y la muerte en un grupo de mexicanos adultos. Tesis de Licenciatura. Universidad Nacional Autónoma de México, México; 2002.

[4] De la Pienda J. Filosofía de las creencias. Rev. Filosofía Univ. Costa Rica. 1999; XXXVII (92): 239-248.

[5] Pajares, F. Teachers' beliefs and educational research: cleaning up a messy construct. Review of Educational Research. 1992; 62 (3), 307-332.

[6] Llinares, S. Conocimiento profesional del profesor de matemáticas: Conocimiento, creencias y contexto en relación a la noción de función. En, Conferencia invitada en el IV Encuentro de Investigación en Educación Matemática. Luso. Portugal. 1995.

[7] Fishbein M, Ajzen I. Belief, Attitude, Intention, and Behavior: An Introduction to Theory and Research. Reading, MA: Addison-Wesley; 1975.

[8] Olson J, Zanna M. Actitudes y Creencias. En: Perlman D, Cosby P, editors. Psicología Social. México: Trillas; 1987: 71-91.

[9] Villoro L. Creer, saber, conocer. México: Siglo XXI; 1996.

[10] Myers D. Psicología Social. México: Mc Graw-Hill /Interamericana; 2005.

[11] Fanon F. Los condenados de la tierra. México: Fondo de Cultura Económica; 1963.

[12] Gastélum M. Una Aproximación a la Epistemología Pluralista Basada en las Teorías de la Mente. En: Duran J, Grande-García I. Psicología y Ciencias Sociales. México: UNAM, FES-Z; 2010: 29-47.

[13] Darwin Ch. El Origen del Hombre. México: Panamericana Editorial; 2002.

[14] Nespor J. The role of beliefs in the practice of teaching. Journal of Curriculum Studies. 1987; 19 (4), 317-328.

[15] Solar M, Díaz C. El profesor universitario: construcción de su saber pedagógico e identidad profesional a partir de sus cogniciones y creencias. Revista Calidad en la Educación. 2009; 30: 207-232.

[16] Fernández M. Creencia y Sentido en las Ciencias Sociales. Ponencia presentada en la sesión privada extraordinaria de la Academia Nacional de Ciencias de Buenos Aires, Argentina; 2006.

[17] Gould S. Ciencia versus religión. Un falso conflicto. Barcelona: Crítica; 2000.

[18] Gould S. Ocho cerditos. Reflexiones sobre historia natural. Barcelona: Critica; 2006.

[19] Russell B. Religión y Ciencia. México: Fondo de Cultura Económica; 2012.

[20] Estany A. La fascinación por el saber. Introducción a la teoría del conocimiento. Barcelona: Crítica; 2001.

[21] Páez D, Morales J, Fernández I. Las creencias básicas sobre 
el mundo social y el yo. En: Morales J, Moya I, Cuadrado I, coordinadores. Psicología Social. España: Mc Graw-Hill /Interamericana; 2007: 195-211.

[22] Ornelas M. La Sociología de la Religión de Niklas Luhmann. En: Luhmann N. Sociología de la Religión. México: Herder; 2009: 9-29.

[23] Schleiermacher F. Sobre la Religión. España: Tecnos; 1990.

[24] Ortega y Gasset J. Ideas y creencias. Madrid: Espasa-Calpe; 1968.

[25] Angarita C. De Castro A. Cara a Cara con la Muerte: Buscando el Sentido. Psicología desde el Caribe. 2002; 9: $1-19$.

[26] Díaz, S. (2005). Tres aproximaciones teóricas al estudio del comportamiento humano. En: Silva J, Grande-García I. Psicología y evolución 2. Filosofía, psicología evolutiva y cognición. México: FES-Z, UNAM; 2005: 99-112.

[27] Pérez V, Gutiérrez M, García A, Gómez J. Procesos Psicológicos Básicos. Un análisis Funcional. España: Pearson. Pretince Hall; 2005.

[28] Lovelock J. Gaia, una nueva visión de la vida sobre la Tierra. Barcelona: Ediciones Orbis; 1985.

[29] Margulis L, Lovelock J. Biological modulation of the Earth's atmosphere. Icarus. 1974; 21, 471-489.

[30] Pardo A. El Origen de la vida y la evolución de las especies. SCRIPTA THEOLOGICA. 2007; 39: 551-572.

[31] Hinchliff C, Stephen S, Allman J, Burleigh G, Chaudhary R, Coghill M, Crandall K, Deng J, Drew B, Gazis R, Gude K, Hibbett D, Katz L, Laughinghouse D, McTavish E, Midford P, Owen C, Ree R, Rees J, Soltis D, Williams T, Cranston K. Synthesis of phylogeny and taxonomy into a comprehensive tree of life. PNAS. 2015; 112 (41): 12764-12769.

[32] Darwin Ch. El Origen de las especies. Madrid. Alianza; 2003.

[33] Zavala A. Darwin y su importancia en la consolidación del pensamiento científico. Entrevista con la Dra. Ana Barahona Echeverría, investigadora y profesora del Departamento de Biología Evolutiva de la Facultad de Ciencias de la UNAM. Revista Digital Universitaria. 2009; 10 (6): 1-9.

[34] Colomina J. El papel de la evolución en la teoría de Daniel Dennett. Arbor. 2004; CLXXIX (705): 247-263.

[35] Damineli A. Damineli D. Origins of life. Estudos Avancados. 2007; 21 (59), 263-285.

[36] Jastrow R. Textos fundamentales. Barcelona: Altaya; 1993.

[37] Dennet D. La Conciencia Explicada. Barcelona: PAIDÓS; 1995.

[38] Pinker S. La Tabla Rasa. La negación moderna de la naturaleza humana. Barcelona: Paidos Transiciones; 2003.

[39] Rojas M. Evolucionismo y Creacionismo. Ciencia UANL. 2006; 9 (003), 246-248.

[40] Dembski W. Diseño Inteligente. Un puente entre ciencia y la tecnología. Miami: Vida; 2005.
[41] Dembski W. En defensa del Diseño Inteligente. Praxis Filosófica. 2007; 24, 147-166.

[42] Teilhard P. Ciencia y Cristo. España: Taurus; 1968.

[43] Tugenhadt E. Egocentricidad y Mistica. Barcelona: Gedisa; 2004.

[44] Ruiz-Mirazo K, Moreno Á. Reflexiones sobre el origen de la vida: algo más que un problema 'evolutivo'. MĖTODE Science Studies Journal. 2015; 87:55-63. DOI 10.7203/metode. 6.4997

[45] Montiel J. El pensamiento de la muerte en Heidegger y Pierre Theilhard de Chardin. Utopía y Praxis Latinoamericana. Revista Internacional de Filosofía Iberoamericana y Teoría Social. 2003; 8: 59-72.

[46] Küng H, Walter J. Morir con dignidad. Un alegato a favor de la responsabilidad. Madrid: Editorial Trotta; 1997.

[47] Ley General de Salud. Título XIV: Donación, trasplantes y pérdida de la vida. [Internet] [Consultado 3 de febrero, 2018] Disponible en:

http://docs.mexico.justia.com/federales/ley_general_de_sal ud.pdf

[48] Asociación Médica Mundial. Declaración de Sídney de la Asociación Médica Mundial sobre la certificación de la muerte y la recuperación de organos. [Internet] [Consultado 5 de enero, 2018] Disponible en: https://www.wma.net/es/policies-post/declaracion-de-sidne y-de-la-amm-sobre-la-certificacion-de-la-muerte-y-la-recu peracion-de-organos/

[49] Hernández F. El significado de la muerte. Revista Digital Universitaria. 2006; 7 (8), 1-7.

[50] Málishev M. El Sentido de la Muerte. Ciencia Ergo Sum. 2003; 10, (1), 51-58.

[51] Jonte-Pace D, Parsons W. Religion and Psychology: mapping the Terrain. EUA: Routledge; 2001.

[52] Jonte-Pace D, Parsons W. The varieties of religious experience. Cambridge, WA: Harvard University Press; 2001.

[53] Von Wobeser G. Cielo, infierno y purgatorio. Durante el Virreinato de la Nueva España. México: UNAM; 2015.

[54] Díez R. Volver al "suelo de creencias". Pensamiento y $\begin{array}{llll}\text { Cultura. 2010; } 13 & \text { (2), 141-155. DOI: }\end{array}$ 10.5294/pecu.2010.13.2.3

[55] Bauman Z. Miedo líquido: la sociedad contemporánea y sus temores. Barcelona. Paidós; 2007.

[56] Legare C, Evans M, Rosengren K, Harris P. The Coexistence of Natural and Supernatural Explanations across Cultures and Development. Child Development. 2012; 83 (3), 779-793.

[57] Moody R. Vida después de la vida. Madrid: Edaf; 2009.

[58] Nature Editorial. Dealing with design. Nature. 2005; 434, 1053.

[59] Larson E, Witham L. Leading scientists still reject God. Nature. 1998; 394 (6691), 313.

[60] Pérez-Agote A, Santiago J. La situación de la religión en 
España a principios del siglo XXI. Madrid: Centro de Investigaciones Sociológicas; 2005.

[61] Zuckerman M, Silberman J, Hall J. The Relation between Intelligence and Religiosity: A Meta-Analysis and Some Proposed Explanations. Personality and Social Psychology Review. 2013; 20 (10), 1-30.

[62] Craig J. Desarrollo Psicológico. México: Prentice Hall; 1997.

[63] Lagos C. Notas sobre Moral y Religión. Theoria. 2007; 16 (2), 25-32.

[64] Nespor J. The role of beliefs in the practice of teaching. Journal of Curriculum Studies. 1987; 19 (4), 317-328.

[65] Park C. Attending to the construct of beliefs in research on religion/ spirituality and health: Commentary on 'Beyond belief'. Journal of Health Psychology. 2012; 17 (7), 969-973.

[66] Gervais W, Norenzayan A. Analytic Thinking Promotes Religious Disbelief. Science. 2012; 336, 493- 496.

[67] Argue A., Johnson D., White L. Age and Religiosity: Evidence from a Three- Wave Panel Analysis. Journal for the Scientific Study of Religion. 1999; 38 (3), 423- 435.

[68] Scheitle C. U.S. College Students' Perception of Religion and Science: Conflict, Collaboration, or Independence? A Research Note. Journal for the Scientific Study of Religion. 2011; 50 (1), 175-186.

[69] Ponte J. Mathematics teachers' professional knowledge. In: Ponte J, Matos J, editors. Proceedings of the eighteenth International Conference for the Psychology of Mathematics Education (PME), Lisboa, Portugal, 1994. 